\title{
KNOWLEDGE AND ATTITUDE ON PREVENTION OF NOSOCOMIAL INFECTIONS OF STUDENTS OF UNIVERSITY OF MOSTAR FACULTY OF HEALTH STUDIES
}

\author{
Ivana Čović, Ivan Vasilj, Antonija Hrkać, Roberta Perković \\ Faculty of Health Studies, University of Mostar, Mostar, Bosnia and Herzegovina
}

Rad je primljen 10.07.2021. Rad je recenziran 17.08.2021. Rad je prihvaćen 29.08.2021.

\begin{abstract}
Introduction: Nosocomial infections are a global problem in the health care system, but they more affect low- and middleincome countries. Educating healthcare professionals about nosocomial infections and prevention strategies to have a significant impact on reducing the number of infections.

Aim: To determine and compare students' knowledge and attitudes about nosocomial infections and prevention strategies at the Faculty of Nursing and Sanitary Engineering from the Faculty of Health Studies and the School of Medicine.

Method: This is a cross-sectional study. The sample consisted of 150 students of third and fourth academic years, both sexes, from the Department of Nursing $(n=50)$, Department of Sanitary Engineering $(n=50)$ of Faculty of Health Studies and the School of Medicine $(n=50)$. The survey was conducted using a self-designed survey questionnaire, divided into three sections: knowledge of nosocomial infections, knowledge of hand hygiene, beliefs, and attitudes about the effect of education on nosocomial infections. Each unit had 5 statements, and the possibility of answering with "YES" or "NO".

Result: Students of all three studies showed, on average, good knowledge of the occurrence and prevention of nosocomial infections. The post-hoc comparison showed significantly higher knowledge of students from the School of Medicine and Sanitary Engineering compared to the knowledge of students from the Department of Nursing $(\mathrm{p}<0.005)$, but not in the hand hygiene test. In the hand hygiene test, a significant difference in overall knowledge was found between the School of Medicine and Sanitary Engineering, in favor of the School of Medicine ( $\mathrm{p}=0.037)$. Most students from all faculties are convinced that knowledge of nosocomial infections and adherence to prevention measures is an important strategy in their prevention.
\end{abstract}

Conclusion: The knowledge of the health-oriented faculties of the University of Mostar is satisfactory. Nevertheless, many students at all faculties consider that education at faculties is insufficient.

Keywords: Nosocomial infections, hospital-acquired infection, knowledge, attitude and practice

Correspondence:

Ivana Čović, Master of Sanitary Engineering

E-mail:ivana.covic@fzs.sum.ba 


\section{INTRODUCTION}

Nosocomial infections are a global public health problem associated with significant morbidity, mortality, as well as the burden and cost of the health system $(1,2)$. The burden of nosocomial infections particularly affects countries with low and middle economic development. According to global burden estimates, prevalence rates in low and middle-income countries are between $5.7 \%-19.1 \%$, and in highincome countries between $5.7 \%-7.5 \%(1,3)$. A literature review (2017) conducted by the European Center for Disease Prevention and Control reported that over 3.2 million patients acquire at least one nosocomial infection in Europe each year with 16 million extra days of hospitalization and 37000 attributable deaths (4).

Nosocomial infections or Hospital-acquired infections are defined as infections acquired in a hospital by a patient admitted for another health reason, not for that infection. Also, nosocomial infections are infections developed by health professionals as a result of their daily work $(5,6)$. The development of an infectious within 48 to 72 hours after admission or within 10 days after discharge from hospital treatment is considered nosocomial infection $(6,7)$. In most cases, nosocomial infections are caused by bacteria, but the cause can also be viruses and fungi. The most common nosocomial infections in patients are urinary tract infections, lower respiratory tract infections, circulatory infections, post-operative infections (surgical site infections), and other bacterial infections $(1,3,8)$. In hospital settings, intensive care units are most susceptible to the development of nosocomial infections(9).

A significant number of nosocomial infections, as well as consequent morbidities and mortality, can be prevented. The health and safety of patients or employees in the workplace should be an important strategy of any healthcare organization. Knowledge and application of prevention strategies in healthcare institutions by health professionals is a key element in maintaining the safety and well-being of patients, but also themselves $(2,8)$. In this process, the significant impact has the quality of education about prevention strategies on the facilities where health professionals have been educated. According to a study from 2007 conducted at the University Hospital of Geneva $(n=2000$ health professionals), the poor level of knowledge affects the implementation and enforcement of prevention strategies for nosocomial infections(10). A study conducted at 31 of the 38
Schools of Medicine in the United Kingdom and the Republic of Ireland found that the issue of nosocomial infections was present in only $60 \%$ of the faculties (11). Data on the quality of education and the level of knowledge about nosocomial infections and their prevention strategies at the faculties of the University of Mostar where future health professionals are educated are not found.

Thus, we conducted the current study to determine the knowledge of future health professionals about nosocomial infections and prevention strategies at the faculties of the University of Mostar.

\section{SUBJECTS AND METHODS}

This was a cross-sectional study. The total sample consisted of 150 participants of both sexes and the average age of the participants was $22(95 \% \mathrm{CI}=22$ to 23) years. The study was conducted at two healthoriented faculties of the University of Mostar, in the third and fourth years of study. The sample of participants was distributed in a ratio of $1: 1: 1$, that is the School of Medicine $(n=50)$ and two departments of the Faculty of Health Studies: Nursing $(\mathrm{n}=50)$ and Sanitary Engineering $(n=50)$.

The study was conducted in March 2018. Participation in the study was voluntary, participants have included in the study after the explanation of the study aims. Refusal to participate had no adverse consequences for the students. Data collection was completely anonymous. This study was approved by the Ethics Committee of both faculties on March 19, 2018.

\section{Questionnaire}

The questionnaire was self-designed for this study. The survey consisted of three parts: i) assessment of knowledge on the occurrence of nosocomial infections, ii) the effect of hand hygiene on the occurrence and prevention of nosocomial infections, and iii) attitudes and beliefs of students on the adequacy of teaching in universities regarding nosocomial infections. Each of these sections consisted of 5 statements, with the option of "Yes" or "No" answers (Supplementary file 1).

\section{Statistical analysis}

Descriptive and inferential statistical methods were used in data analysis. Categorical data are presented in frequencies, and the significance analysis of the difference between categorical variables was performed by the Chi-Square test. The distribution of quantitative variables deviated from normal (analyzed by Kolmogorov-Smirnov test); thus, descriptive data were presented by nonparametric methods. Quantitative data were presented by the median and interquartile range 
Čović I, Vasilj I, Hrkać A, Perković R. Knowledge and attitude on prevention of nosocomial infections of students of University of Mostar Faculty of health studies. Zdravstveni glasnik. 2021;7(2):73-82.

(25 to 75 percentile).In both tests (determination of knowledge about NI and hands hygiene) was determined the level of knowledge; poor knowledge was $<3$ correct answers and good knowledge was $\geq 3$ correct answers. The difference in knowledge between the three study programs was tested by the KruskalWallis test. Post-hoc analysis of the significance of the effect between groups was tested by Dunn's multiple comparisons with Bonferroni correction of the Kruskal-Wallis test. Differences in the knowledge according to study years and sex were analyzed by the Mann-Whitney U test. In all tests (two-sided), the significance level was $\mathrm{p}<0.05$. Statistical software IBM SPSS Statistics 23 (Armonk, NY: IBM Corp.) was used for data analysis.

\section{RESULTS}

The total sample consisted of 150 participants. Women were more represented than men $(n=112,74.7 \%)$. The average (median, 95\% confidence interval) age in the total sample was 22 (22 to 23).

Knowledge of nosocomial infections and hand hygiene The frequency of correct answers from the test of risk factors for nosocomial infections and hand hygiene test are shown in Table 1. Several statements revealed a significant difference in correct and incorrect answers between faculties, but in the final sum of correct answers, there was no difference between the knowledge on both the nosocomial infections test and the hand hygiene test.

Table 1. Comparison of knowledge of students of Medicine $(n=50)$, Nursing $(n=50)$, and Sanitary Engineering $(n=50)$ at the test of the risk factors for the development of nosocomial infection and the effect of hand hygiene

No. (\%) of students who correctly responded to the statement* per faculties; (Total n=150)

Test statements

$\begin{array}{cc}\text { Medicine } \quad \text { Nursing } & \text { Sanitary } \\ \text { engineering }\end{array}$

$\mathrm{P} \dagger$

\begin{tabular}{|c|c|c|c|c|}
\hline Nosocomial infections test & & & & \\
\hline Older age or extremely young age (children and the elderly) & & & & \\
\hline increase the risk of nosocomial infections. & $43(86)$ & $30(60)$ & $47(94)$ & $<0.001$ \\
\hline All patients can be a source of infection regardless of the & & & & \\
\hline medical diagnosis. & $37(74)$ & $49(98)$ & $45(90)$ & 0.001 \\
\hline All body fluids (except sweat) should be considered a possible & & & & \\
\hline source of infection. & $45(90)$ & $47(94)$ & $47(94)$ & 0.675 \\
\hline The environment (air, water, inert surfaces) is the main source & & & & \\
\hline of bacteria that cause nosocomial infection. & $14(28)$ & $11(22)$ & $12(24)$ & 0.778 \\
\hline $\begin{array}{l}\text { Standard work precautions apply only to healthcare workers } \\
\text { exposed to body fluids. }\end{array}$ & $34(68)$ & $10(20)$ & $27(54)$ & $<0.001$ \\
\hline Hand hygiene test & & & & \\
\hline $\begin{array}{l}\text { Personal hygiene of health care professionals is an important } \\
\text { factor in the prevention of nosocomial infection }\end{array}$ & $45(90)$ & $49(98)$ & $48(96)$ & 0.180 \\
\hline Hand hygiene is the most effective, simplest and most & & & & \\
\hline economical way to prevent nosocomial infection & $49(98)$ & $48(96)$ & $50(100)$ & 0.360 \\
\hline $\begin{array}{l}\text { Liquid soap and water are sufficient to remove 98\% of } \\
\text { transient microbial flora on the hands. }\end{array}$ & 17 (34) & 16 (32) & $12(24)$ & 0.513 \\
\hline
\end{tabular}


Čović I, Vasilj I, Hrkać A, Perković R. Knowledge and attitude on prevention of nosocomial infections of students of University of Mostar Faculty of health studies. Zdravstveni glasnik. 2021;7(2):73-82.

$\begin{aligned} & \text { The effect of hygienic hand washing depends on the length of } \\ & \begin{array}{l}\text { washing time and hand movements } \\ \text { Before disinfecting your hands with alcohol, it is necessary to }\end{array}\end{aligned}$
$\begin{aligned} & \text { wash your hands hygienically. } \\ & \text { * }\end{aligned}$

*Option of "Yes" or "No" answers

†Chi-Square statistical significance of comparison of the frequency of correct answers, by faculty groups; Statistical significance is in bold.

\section{Differences in overall knowledge}

According to the results of the overall success of the surveys, a statistically significant difference in knowledge was found between the three faculties in nosocomial infections and hand hygiene tests. However, the average level of knowledge in both tests was $\operatorname{good}(\geq 60 \%)$ in all faculties (Table 2).

Table 2. Comparison of knowledge of students of Medicine $(n=50)$, Nursing $(n=50)$, and Sanitary Engineering $(\mathrm{n}=50)$ at the Nosocomial infections test

№. (\%) of students per faculty who responded to the test per faculty(Total $n=150)$

Medicine

Nursing

Sanitary Engineering

\section{P}

Nosocomial infections test
$-(-)$

$3(6)$

14 (23)

$22(44)$

$8(16)$

$3(6)$

$60(60$ to 60)
1(2)

$1(2)$

2(4)

19 (38)

19 (38)

$8(16)$

$80(60$ to 80$)$
None

$1(20 \%)$

$2(40 \%)$

$3(60 \%)$

$4(80 \%)$

$5(100 \%)$

Average knowledge \%*

$1(2)$

$1(2)$

6(12)

$13(26)$

$25(50)$

$4(8)$

$80 \quad(60$ to

80)

Hand hygiene test

None

$1(20 \%)$

$2(40 \%)$

$3(60 \%)$

$4(80 \%)$

$5(100 \%)$

Average knowledge \%*
$-(-)$

2(4)

$4(8)$

$17(34)$

17 (34)

$10(20)$

$80 \quad(60$ to

80)
$<0.0$

01

0.00

3

6

5

6

1

\section{.}


Post-hoc analysis showed that students of the School of Medicine and students of Sanitary Engineering have a higher level of knowledge about risk factors for developing a nosocomial infection compared to nursing students. In the hand hygiene test, a significant difference in students' level of knowledge was found only between the School of Medicine and Sanitary Engineering, in favor of the School of Medicine (Table $3)$.

Table 3. Post-hoc comparison of the level of knowledge in nosocomial infections and hand hygiene tests

$$
\text { Nosocomial infections test Hand hygiene test }
$$

\begin{tabular}{lllll} 
Faculty group & $\begin{array}{l}\text { Test } \\
\text { statistics }\end{array}$ & $\begin{array}{l}\text { P. } \\
\text { value }\end{array}$ & $\begin{array}{l}\text { Test } \\
\text { statistics* }\end{array}$ & P-value \\
\hline Medicine vs Nursing & -26.79 & 0.004 & -17.04 & 0.087 \\
Medicine vs Sanitary Engineering & -3.60 & 1.000 & -19.56 & 0.037 \\
Nursing vs Sanitary Engineering & -30.39 & 0.001 & 2.52 & 1.000
\end{tabular}

In the Nursing program, a significant difference in the level of knowledge in the nosocomial infections test was found between the third and fourth study years. Third-year students of Nursing showed average poor knowledge of nosocomial infections. All other students showed good knowledge of nosocomial infections and prevention strategies (Figure 1).

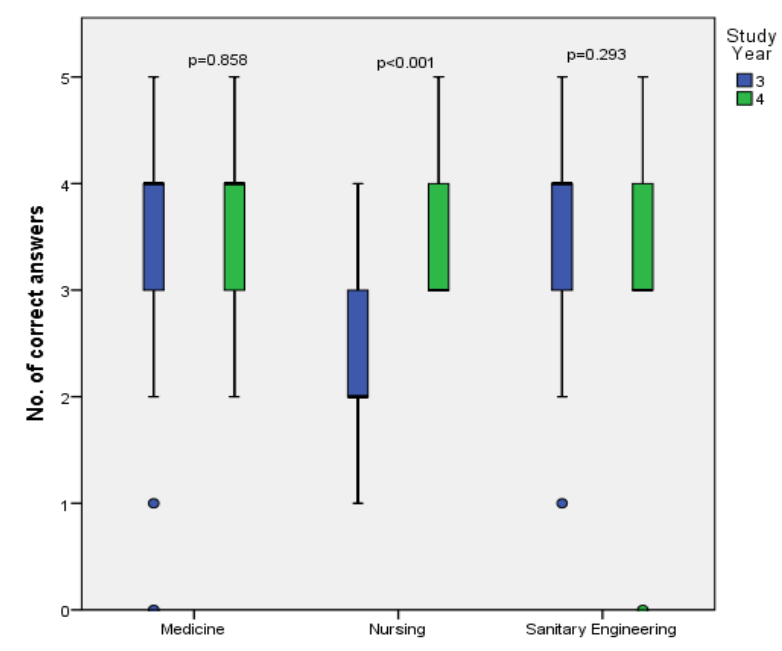

Figure 1.The level of knowledge students of the School of Medicine and the Faculty of Health Studies from the University of Mostar about risk factors for the development of nosocomial infections.

In the hand hygiene test, there was no difference in the level of knowledge between study years in any faculty group. Students from both academic years at all faculties have a good level of knowledge about hand hygiene as a preventive strategy ( $\geq 3$ correct answers) (Figure 2). The majority of fourth-year Nursing students (68\%) and third-year Sanitary Engineers students (72\%) correctly answered 3 of the 5 offered claims in the hand hygiene test, with an established average of $3(95 \% \mathrm{CI}=3$ to 3 ) correct answer (Figure 2, Table 2). 


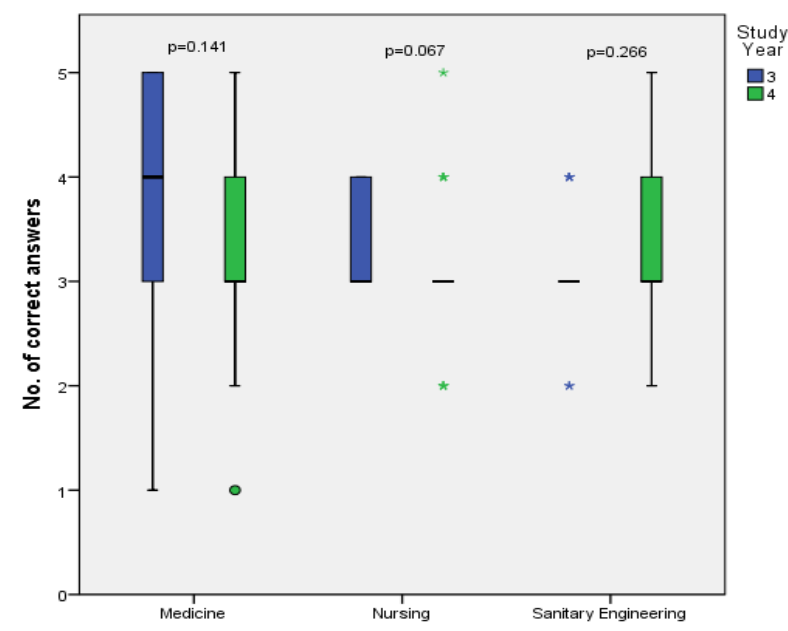

Figure 2. The level of knowledge students of the School of Medicine and the Faculty of Health Science from the University of Mostar at the hand's hygiene test.

There was no significant difference between male and female students in level of knowledge in nosocomial infections test $(\mathrm{U}(1, \mathrm{n}=150)=2.06 ; \mathrm{p}=0.747)$, as well as hand hygiene test $(\mathrm{U}(1 ; \mathrm{n}=150)=2.05 ; \mathrm{p}=0.693)$.

\section{Students' Attitudes and beliefs}

Attitudes and beliefs of students of the School of Medicine and the Faculty of Health Studies of the University of Mostar on the adequacy of education in the studied study programs, as well as its role in the prevention of nosocomial infections, are shown in
Table 4. A significant difference in the answers of students by faculties and study program was found in all statements, except in satisfaction with the theoretical teaching of nosocomial infections. Most students are convinced that education at faculties is insufficient, except for students of the School of Medicine where more than half of the participants expressed satisfaction with practical education. However, a sufficient number of students of the School of Medicine and Sanitary Engineering believe that the provided knowledge is sufficient for future work.

Table 4. Comparisons of positive and negative attitudes and beliefs of students of Medicine ( $n=50)$, Nursing ( $n=50)$, and Sanitary Engineering $(\mathrm{n}=50)$ about nosocomial infections

Attitudes/Beliefs of students

\begin{tabular}{|c|c|c|c|c|c|}
\hline & $\begin{array}{l}\text { Medic } \\
\text { ine }\end{array}$ & $\begin{array}{l}\text { Nursi } \\
\mathrm{ng}\end{array}$ & $\begin{array}{l}\text { Sanitary } \\
\text { Engineeri } \\
\text { ng }\end{array}$ & ${ }_{2}^{\chi}$ & $p$ \\
\hline $\begin{array}{l}\text { Transfer of the theoretical knowledge in the } \\
\text { program was satisfactory }\end{array}$ & $\begin{array}{l}20 \\
(40)\end{array}$ & $\begin{array}{l}16 \\
\text { (32) }\end{array}$ & $14(28)$ & $\begin{array}{l}1 \\
6 \\
8\end{array}$ & $\begin{array}{l}0.4 \\
32\end{array}$ \\
\hline $\begin{array}{l}\text { Transfer of the practical knowledge in the } \\
\text { program was satisfactory }\end{array}$ & $\begin{array}{l}27 \\
(54)\end{array}$ & $\begin{array}{l}17 \\
(34)\end{array}$ & $13(26)$ & $\begin{array}{l}8 \\
8 \\
8 \\
3\end{array}$ & $\begin{array}{l}0.0 \\
12\end{array}$ \\
\hline
\end{tabular}


Čović I, Vasilj I, Hrkać A, Perković R. Knowledge and attitude on prevention of nosocomial infections of students of University of Mostar Faculty of health studies. Zdravstveni glasnik. 2021;7(2):73-82.

Nosocomial infections are a result of insufficient knowledge of the staff

Large number of nosocomial infections can be prevented

The knowledge provided at the faculties is sufficient for future work
$30 \quad 38$

(60)

(76)

$42(84)$

0.0

22

6

4

$34 \quad 38$

(68) (76)

$46(92)$

0.0

(46)

22

8

. 12

9

0

(70)

$32(64)$

$\begin{array}{ll}6 & 0.0\end{array}$

39

5

0 


\section{DISCUSSION}

The knowledge about nosocomial infections as well the importance of proper hand hygiene in their prevention by students of the University of Mostar is satisfactory; the average level of knowledge in both tests was $60 \%$. The students of the School of Medicine showed the highest knowledge in both tests. In the test of nosocomial infections and the importance of prevention strategies, the least knowledge was showed students of the Nursing program from the Faculty of Health Studies (FHS); there was significantly less compared with other studies programs. In the Hand Hygiene test students of the study program of Sanitary Engineering showed the significantly least knowledge compared with students of the School of Medicine Medicine, but without a significant difference in knowledge in comparison of the studies programs from FHS, Sanitary Engineering and the Nursing.

Similar findings as in our study were found in a study conducted in Osijek in 2016, which involved 316 students from three study programs: Medicine, Nursing, and Medical Laboratory Diagnostics. Students showed an adequate level of knowledge on the prevention of nosocomial infections and an insufficient level of knowledge on the proper implementation of hand hygiene was observed, more precisely on the indications for hand disinfection with alcoholic preparations (antiseptics). Students of Medical Laboratory Diagnostics showed greater knowledge of nosocomial infections compared with other study programs (12).

On the other side, knowledge of nosocomial infections among our students is greater than knowledge of students from two studies conducted in Italy in 2011 and 2015. In a 2011 study (Colosi and colleagues), the level of knowledge about nosocomial infections was surveyed on a sample of 117 students of Medicine and Nursing, while in a 2015 study (Pasquarella and colleagues), the sample consisted of 510 dental students from seven Italian universities. In both studies were determined sufficient knowledge in the field of standard precautions at work, while the results in the field of hand hygiene were somewhat weaker, and knowledge of nosocomial infections themselves was classified as insufficient $(13,14)$.

In a recently published study (Bayleyegn and colleagues, 2021) conducted at the University of Gondar Comprehensive Specialized Hospital, North West Ethiopia, and where the sample consisted of 236 health care workers, is determined good knowledge about nosocomial infections (90\%) and $57.2 \%$ of them have positive beliefs toward nosocomial infections prevention. However, only $36 \%$ of the health workers surveyed in this study had good practice in nosocomial infection prevention; the level of education and work experience was significantly related to the attitude and practice of NI prevention $(\mathrm{p}<0.005)(15)$. In our study, more than half of the surveyed students from the School of Medicine and the Department of Sanitary Engineering of the FHS believed that the education provided at the faculties was sufficient for future work ( $70 \%$ vs $64 \%$ ), unlike the students of the Department of Nursing where less than half of the respondents (46\%) had an attitude. However, less than half of the students at all faculties believe that theoretical teaching at the faculties is sufficient (Medicine 40\% vs. Sanitary Engineering 28\% vs. Nursing $32 \%)$. When it comes to practical teaching about nosocomial infections, the Students of the School of Medicine had more positive attitudes compared to theoretical teaching, while FHS students expressed positive attitudes in a sufficiently similar ratio as for theoretical teaching. However, most students of the School of Medicine and the Sanitary Engineering program, but not the Nursing program, are convinced that the education provided to them is sufficient for future work. Also, the results of our study and the established knowledge and attitudes are sufficiently comparable with previously established knowledge and attitudes in terms of disease prevention and better quality of work from similar studies conducted at the University of Mostar, among students and health professionals $(16,17)$.

It is quite clear that the knowledge of health professionals about nosocomial infections is a key strategy for their prevention, as well as that the basic knowledge about nosocomial infections is acquired during schooling or study $(6,11,18,19)$. In our study, students showed good knowledge about nosocomial infections, which assumes that the application of the same will have its benefits during implementing prevention strategies in the future work of our students. By applying the acquired knowledge about nosocomial infections, our students will protect themselves, patients, and the health care system in general. The obtained significant difference in answers between studies in terms of standard precautions gives us a new motive for additional education first in the study of nursing (most incorrect answers), but also the other two studies (uncertainty about the answers).

The most important aspect of infection control and prevention of nosocomial infections is hand hygiene (20-22). In addition to importance, hand hygiene is also the simplest way to prevention strategy of nosocomial infections (23). Routine hand hygiene removed pathogenic microorganisms that are transiently on the 
healthcare worker and in that way limits the risk of transmission to the patient. Hand hygiene also prevents colonization and infection in the healthcare worker and the contamination of the environment (20). The World Health Organization (WHO) has identified five moments in which hand hygiene should always be practiced: before touching a patient, before any clean or aseptic procedure, after exposure to body fluid, after touching a patient, and after touching patient surroundings (24). According to the WHO, in most situations, alcohol disinfectants should be used in the process of hand hygiene, while handwashing with soap and water is used for visible soiling of hands (eg. blood) and preparation for surgical procedures (25). Voss and colleagues (2006) state that cleaning hands with a disinfectant (eg. alcohol) is a simple and undemanding procedure; does not require prior thorough hand washing, lasts only a few seconds, and means a lot for the prevention of nosocomial infections (26). Our study indicated that knowledge of the importance of hand hygiene is not satisfactory in a sufficient number of students, especially from FHS. In addition, a sufficient number of FHS students did not know that the application of alcoholic disinfectants does not require prior handwashing with soap and water. However, in our study, the moments in which both handwashing methods were applied were not specified in detail, which could have had an impact on the obtained results of knowledge of FHS students. This is the limitation of this study. The limitation of this study is certainly an applied questionnaire prepared only for the purposes of this study; In addition to being able to influence the biased knowledge of our students, it is not standardized, but self-designed.

In addition to the above limitations, this study has several strengths. First, this is the first study to indicate the level of knowledge about nosocomial infections among students of our University. The results of this study should in any case be an incentive to include additional education (both theoretical and practical) in faculties. Second, this study indicates what this additional education should contain; pay more attention to hand hygiene with a more detailed explanation of the same. Finally, this study should be an incentive to conduct a new, methodological of better quality study.

\section{CONCLUSION}

Knowledge and beliefs about nosocomial infections among students from University in Mostar are satisfactory. Although satisfactory knowledge and positive beliefs are present in a larger number of students and the fact that most students are convicted that present knowledge is sufficient for future work, the results indicate the need for additional education on nosocomial infections. Additional education is especially needed in the area of hand hygiene.

\section{REFERENCES}

1. WHO. Report on the Burden of Endemic Health Care-Associated Infection Worldwide. A systematic review of the literature; [Internet]2011 [Cited 2021 Feb.26]. Available from: https://apps.who.int/iris/bitstream/handle/10665/80135/ 9789241501507_eng.pdf?sequence $=1$.

2. Manoukian S, Stewart S, Dancer S, Graves N, Mason $\mathrm{H}, \mathrm{McF}$ arland A, et al. Estimating excess length of stay due to healthcare-associated infections: a systematic review and meta-analysis of statistical methodology. The Journal of hospital infection. 2018;100(2):222-35.

3. ECDC. Point prevalence survey of healthcareassociated infections and antimicrobial use in European Acute Care Hospitals: 2011-2012. Stockholm [Internet] ECDS; 2013 [Cited 2021 Feb.26]. Available from: https://www.ecdc.europa.eu/en/publications-data/pointprevalence-survey-healthcare-associated-infections-andantimicrobial-use-4.

4. ECDC. Economic evaluations of interventions to prevent

healthcare-associated infections: literature review Stockholm[Internet]: ECDC; 2017 [Cited 2021 Feb.26]. Available from:

https://www.ecdc.europa.eu/en/publicationsdata/economic-evaluations-interventions-preventhealthcare-associated-infections.

5. Curtis DE, Hlady CS, Kanade G, Pemmaraju SV, Polgreen PM, Segre AM. Healthcare worker contact networks and the prevention of hospital-acquired infections. PloS one. 2013;8(12):e79906.

6. Bayleyegn B, Mehari A, Damtie D, Negash M. Knowledge, Attitude and Practice on Hospital-Acquired Infection Prevention and Associated Factors Among Healthcare Workers at University of Gondar Comprehensive Specialized Hospital, Northwest Ethiopia. Infection and drug resistance. 2021;14:259-66.

7. Meena P, Gaurav P. ASSESSMENT OF HEALTH CARE PROFESSIONALS KNOWLEDGE, ATTITUDE AND PRACTICE TOWARDS INFECTION CONTROL IN LABOUR ROOM. International Journal of Ayurveda and Pharma Research. 2016;4(4). 
8. Saleem Z, Godman B, Hassali MA, Hashmi FK, Azhar F, Rehman IU. Point prevalence surveys of health-care-associated infections: a systematic review. Pathogens and global health. 2019;113(4):191-205.

9. Haque M, Sartelli M, McKimm J, Abu Bakar M. Health care-associated infections - an overview. Infection and drug resistance. 2018;11:2321-33.

10. Sax H, Allegranzi B, Uckay I, Larson E, Boyce J, Pittet D. 'My five moments for hand hygiene': a usercentred design approach to understand, train, monitor and report hand hygiene. The Journal of hospital infection. 2007;67(1):9-21.

11. Humphreys $\mathrm{H}$ RJ. Undergraduate and postgraduate medical education on the prevention and control of healthcare-associated infection. More progress is needed. [Internet]: IJIC 2011;7(2) [Cited 2021 Feb.26]. Available from: https://www.ijic.info/article/view/7127.

12. Tomić A. Znanja, stavovi i praksa studenata Medicinskoga fakulteta u Osijeku o sprječavanju nastanka bolničkih infekcija [Internet]: Josip Juraj Strossmayer University of Osijek. Faculty of Medicine; 2016 [Cited 2021 Feb.26]. Available from: https://repozitorij.mefos.hr/islandora/object/mefos\%3 A241/datastream/PDF/view.

13. Colosi A, Ergasti G, Murzilli G, Paolini V, Semeraro V, Trapani MM, et al. Healthcare students and their knowledge of healthcare-associated infections. Annali di igiene : medicina preventiva e di comunita. 2011;23(3):203-8.

14. Pasquarella C, Veronesi L, Castiglia P, D'Alessandro D, Legnani P, Minelli L, et al. Prevention of healthcare-associated infections: knowledge among dental students in seven Italian universities. Annali di igiene : medicina preventiva e di comunita. 2015;27(3):546-53.

15. Bayleyegn BA-O, Mehari A, Damtie DA-O, Negash MA-O. Knowledge, Attitude and Practice on Hospital-Acquired Infection Prevention and Associated Factors Among Healthcare Workers at University of Gondar Comprehensive Specialized Hospital, Northwest Ethiopia. (1178-6973 (Print)).

16. Perković R, Medić A, Vasilj I. ZNANJE, STAV I PRAKSA ZDRAVSTVENIH DJELATNIKA O OBVEZNOM CIJEPLJENJU NA PODRUČJU HERCEGBOSANSKE ŽUPANIJE. Zdravstveni Glasnik. 2015;2:55-60.

17. Jurilj M, Jerković A, Šimić J. Stavovi i znanje zdravstvenih djelatnika o primjeni prakse zasnovane na dokazima u radiologiji. Zdravstveni Glasnik. 2020;6(2):53-60.

18. Maitanmi J, Anise I. Original Article Knowledge and Preventive Practices of Nosocomial Infections among Health Workers in Two Selected Tertiary Hospitals in Ogun State. 2021.

19. Khazaei S, Khazaei S, Ayubi E. Importance of Prevention and Control of Nosocomial Infections in Iran. Iranian Journal of Public Health. 2018;47:307-8.

20. Sikora A, Zahra F. Nosocomial Infections. [Internet]: In: StatPearls [Internet]. Treasure Island (FL): StatPearls Publishing; 2021 Jan-. [Updated 2021 Aug 10]. [Cited 2021 Oct. 22]. Available from: https:/www.ncbi.nlm.nih.gov/books/NBK559312/.

21. Fox C, Wavra T, Drake DA, Mulligan D, Bennett YP, Nelson C, et al. Use of a Patient Hand Hygiene Protocol to Reduce Hospital-Acquired Infections and Improve Nurses' Hand Washing. American Journal of Critical Care. 2015;24(3):216-24.

22. Haverstick S, Goodrich C, Freeman R, James S, Kullar R, Ahrens M. Patients' Hand Washing and Reducing Hospital-Acquired Infection. Critical care nurse. 2017;37(3):e1-e8.

23. Pittet D, Allegranzi B, Sax H, Dharan S, Pessoa-Silva CL, Donaldson L, et al. Evidence-based model for hand transmission during patient care and the role of improved practices. The Lancet Infectious diseases. 2006;6(10):641-52.

24. Mathai E, Allegranzi B, Kilpatrick C, Pittet D. Prevention and control of health care-associated infections through improved hand hygiene. Indian journal of medical microbiology. 2010;28(2):100-6.

25. WHO. WHO Guidelines on Hand Hygiene in Health Care: First Global Patient Safety Challenge Clean Care Is Safer Care. Geneva: World Health Organization[Internet]2009 [Cited 2021 Oct. 23]. Available from: https://www.ncbi.nlm.nih.gov/books/NBK144013/.

26. Voss A, Widmer AF. No Time for Handwashing!? Handwashing Versus Alcoholic Rub Can We Afford $100 \%$ Compliance? Infection Control \& Hospital Epidemiology. 2015;18(3):205-8. 